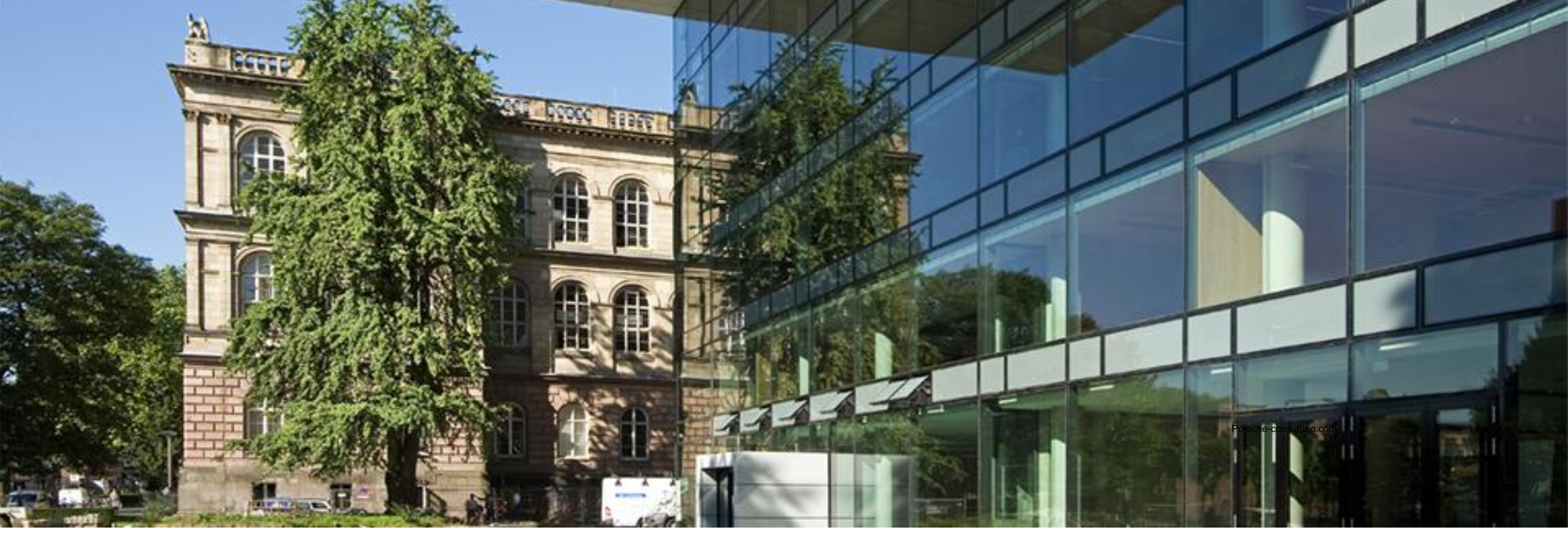

\title{
Assessment of a Fuel Cell Powered Air Taxi in Urban Flight Conditions
}

Michael Husemann, M.Sc.

Christopher Glaser, B.Sc.

Univ.-Prof. Dr.-Ing. Eike Stumpf

Institute of Aerospace Systems (ILR) 


\section{Challenges of today's mobility concepts}

\section{Current Situation}

\begin{tabular}{|c|l|}
\hline & - Daily routine (commuting, free time) \\
Mobility & - Travels (regional/ trans-regional) \\
Needs & - Tendency towards ind. transport \\
& - benefits are cost-intensive \\
& - usage of cars not optimal \\
\hline
\end{tabular}
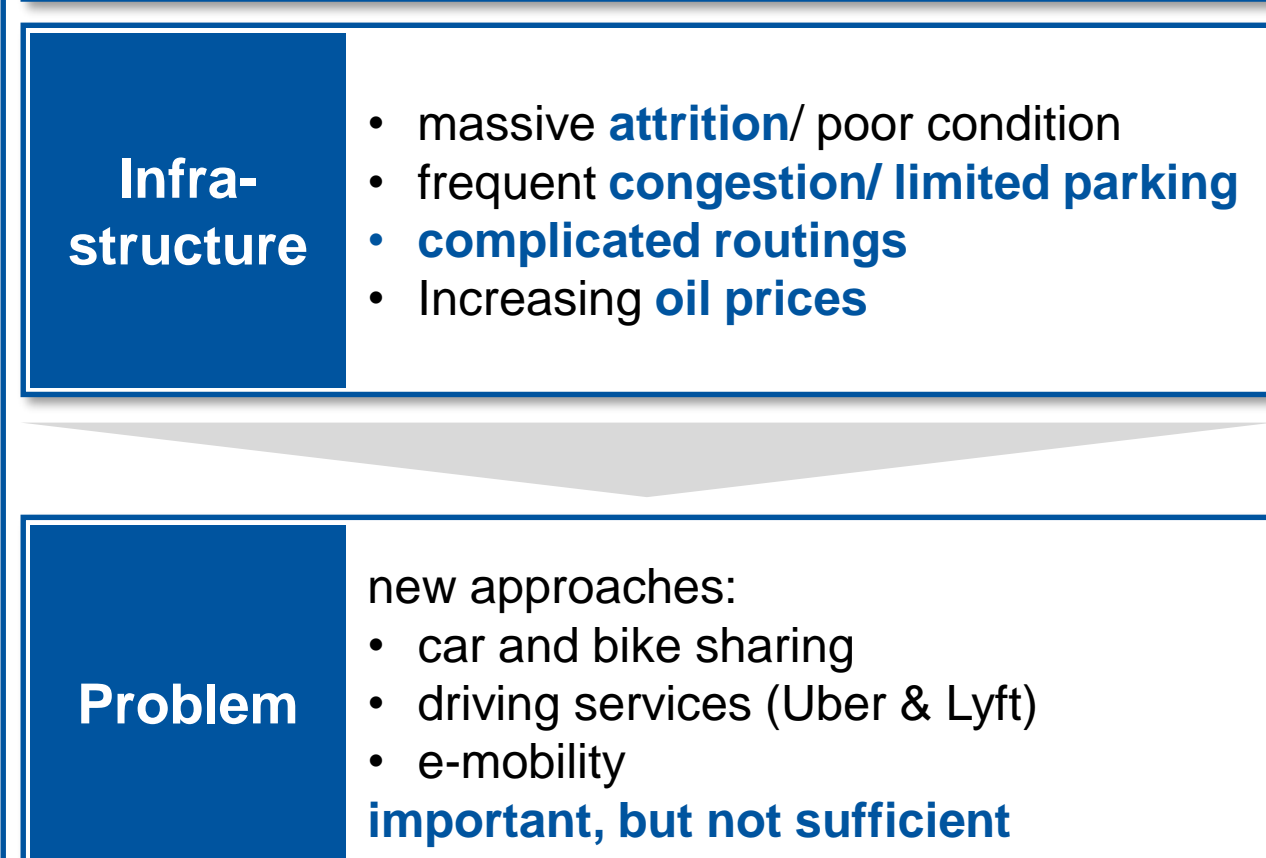

Requirements

\section{External Demands and Requirements}

\section{Political Guidelines}

- door-to-door-travel time of max. 4 hours (Flightpath 2050)

- Environmental requirements or health concerns (noise und pollutants)

- Operating costs

\section{User Groups}

Various requirements for a high level of comfort:

- Punctuality/ Predict.

- Accessibility

- 24/7 availability

- Individ. planning

- Short travel times

- comfortable

- Internet access

- inexpensive

- Environmentally friendly (noise und pollutants)
Mobility plays an important role in daily life

$\Rightarrow$ Mobility that increases speed, decreases costs, more readily available 


\section{Modern technologies enable new transportation possibilities}

\section{Alternative Options}

\section{(1) Use of the "third dimension"}

- Diversified mobility options

- Opportunity of individualized mobility (ondemand)

- Travel distance corresponds to approx. linear distance, which is why travel duration is shorter than with conventional mobility concepts

- Bypassing areas at risk of congestion

(II)

\section{Different application cases}

- Regional air transport

for ranges between $50 \mathrm{~km}<\mathrm{s}<500 \mathrm{~km}$

- Suburban air transport

for commuting purposes \& feeder services

- Urban air transport daily transportation (leisure and commuting)

Design Concepts

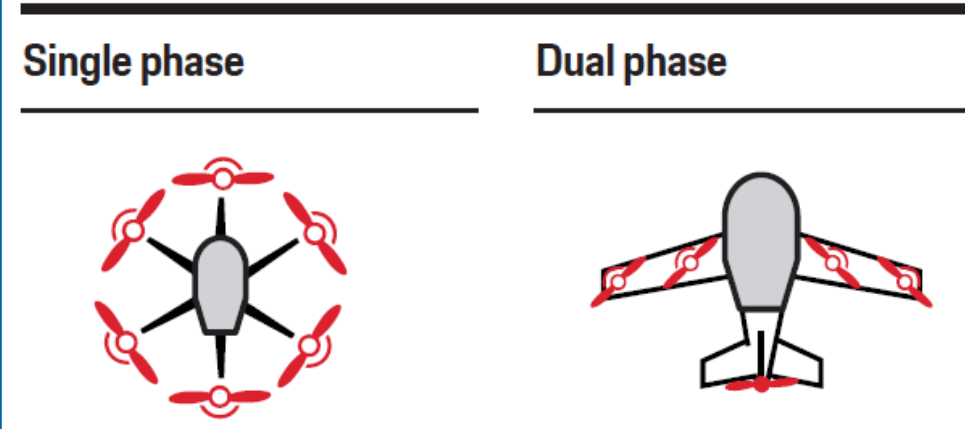

MULTIROTOR

lift
LIFT AND CRUISE

combination
Transition phase

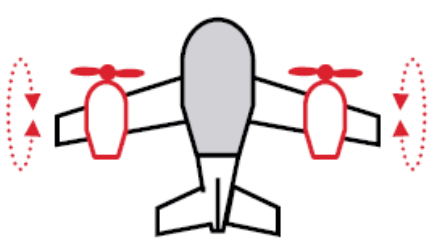

TILT-X

tilt-wing, tilt-rotor, tilt-duct 


\section{Modern technologies enable new transportation possibilities}

\section{Alternative Options}

\section{(1) Use of the "third dimension"}

- Diversified mobility options

- Opportunity of individualized mobility (ondemand)

- Travel distance corresponds to approx. linear distance, which is why travel duration is shorter than with conventional mobility concepts

- Bypassing areas at risk of congestion

Different application cases

- Regional air transport for ranges between $50 \mathrm{~km}<\mathrm{s}<500 \mathrm{~km}$

- Suburban air transport

for commuting purposes \& feeder services

- Urban air transport

daily transportation (leisure and commuting)

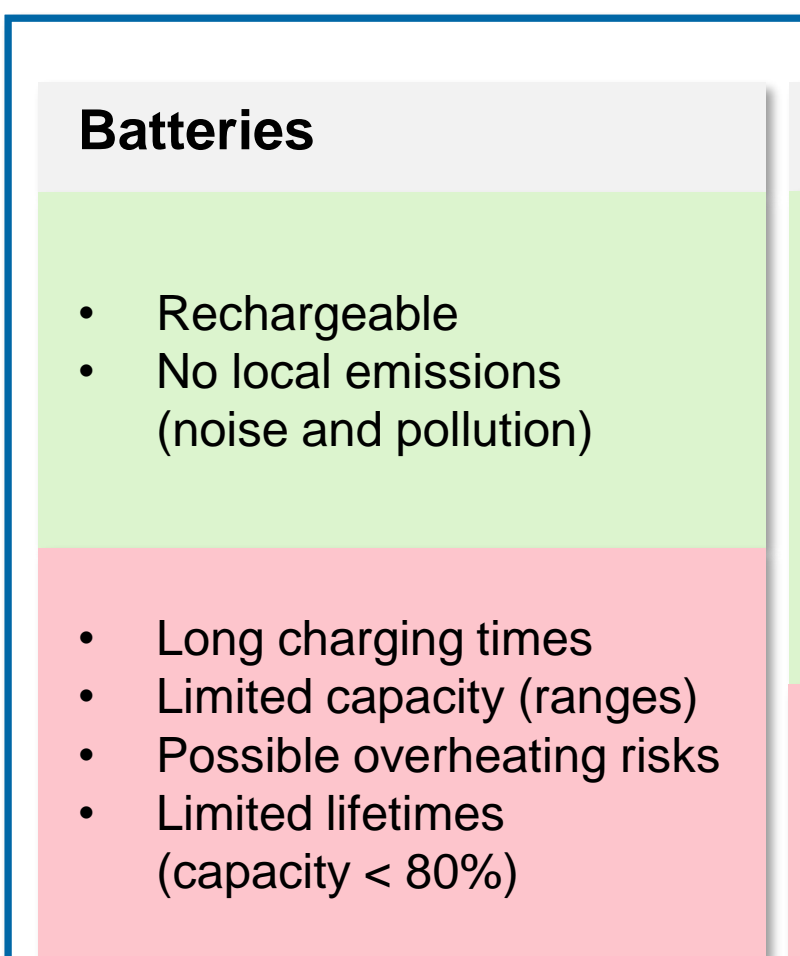

\section{Fuel Cells}

- Short refueling times

- High power density

- High energy conversion efficiency

- "No" local emissions (noise \& pollution)

- Complex design

- Thermo management

- Missing infrastructure

\section{Does the application of fuel cells in air transportation offer operational benefits?}




\section{Considerations are based on the initial battery powered Vahana concept}

A simplified version of the original design tool is available to the public

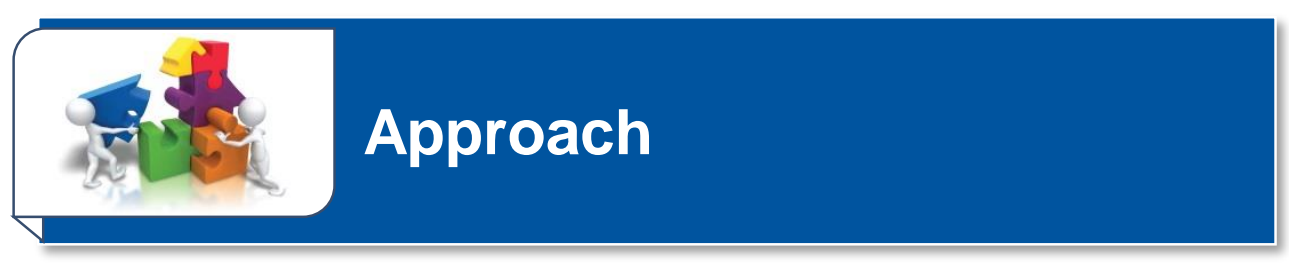

\section{Reference vehicle}

A - Characteristics

Vahana concepts

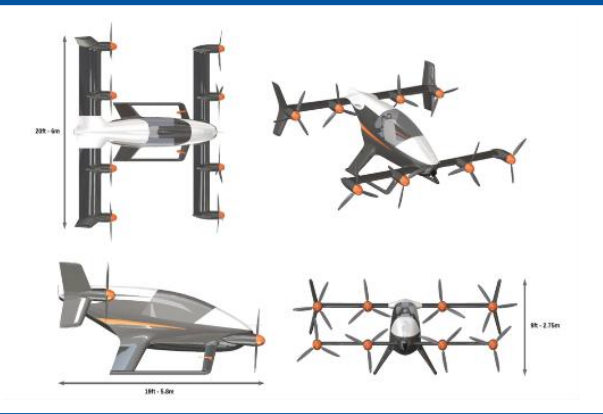

\section{Principles of fuel cells}

B - Energy storage

Equivalent specific energy

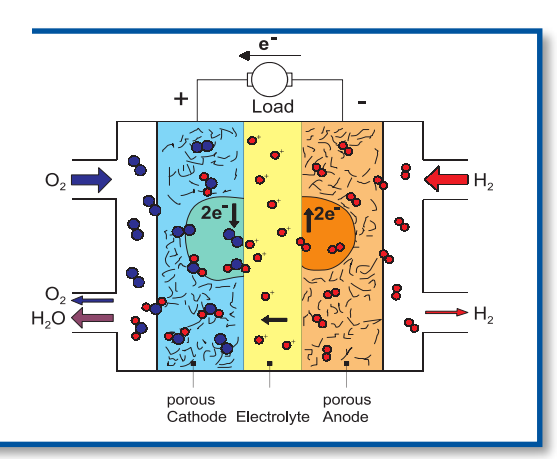

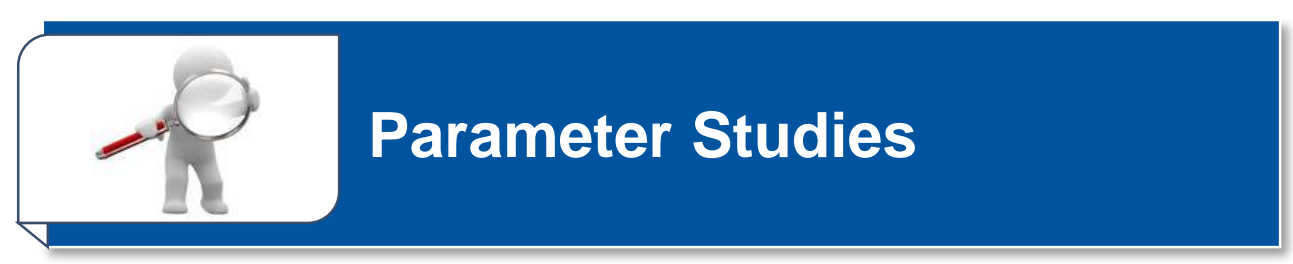
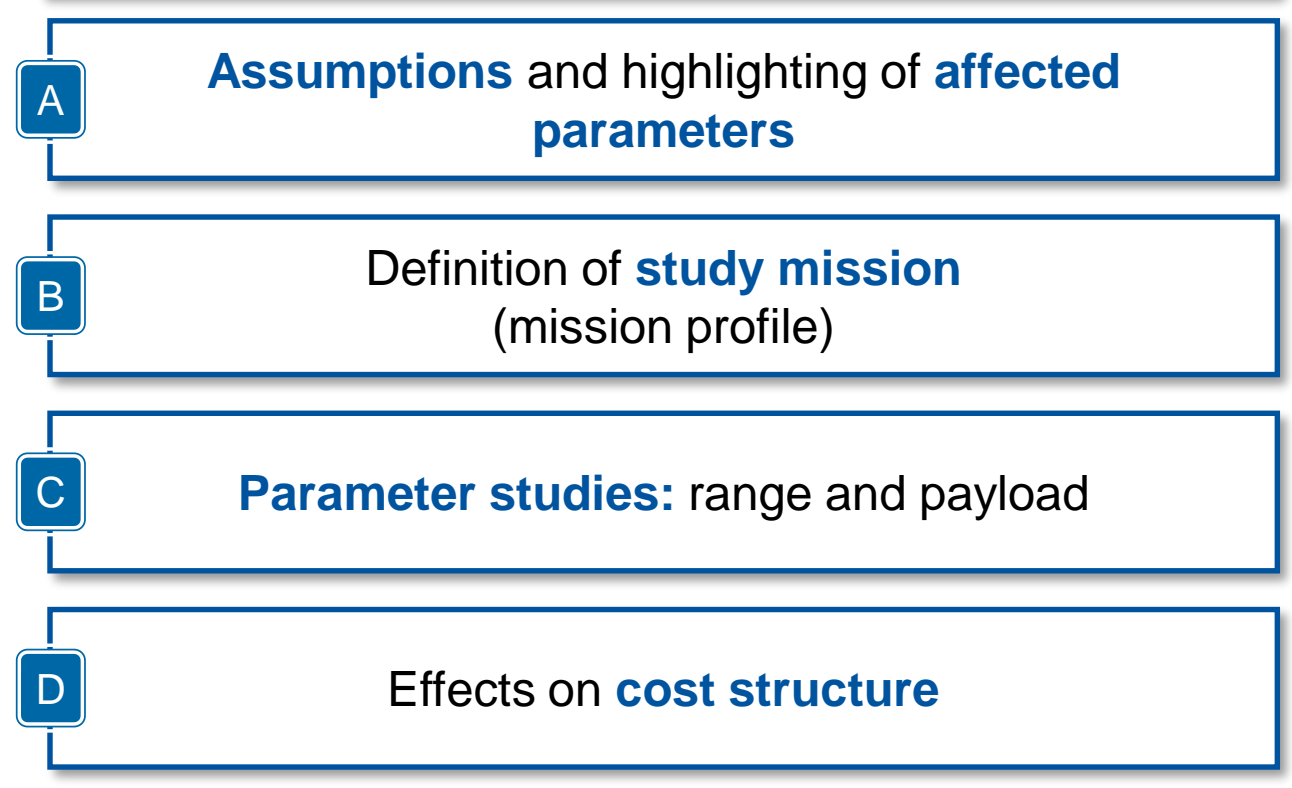

E Conclusions




\section{Considerations are based on the initial battery powered Vahana concept}

A simplified version of the original design tool is available to the public

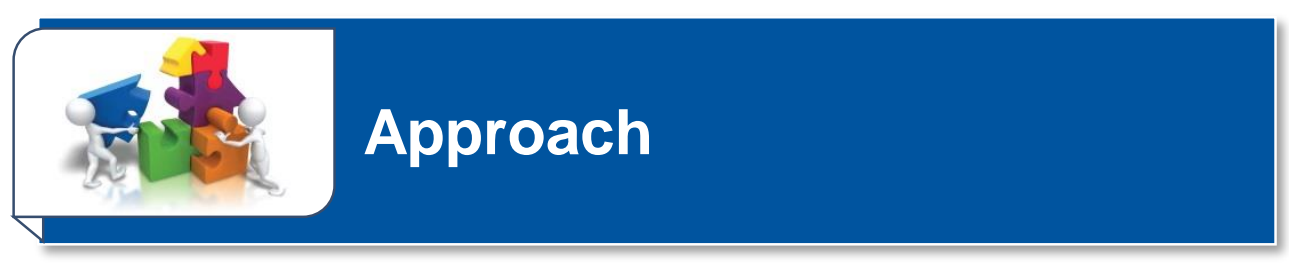

Reference vehicle

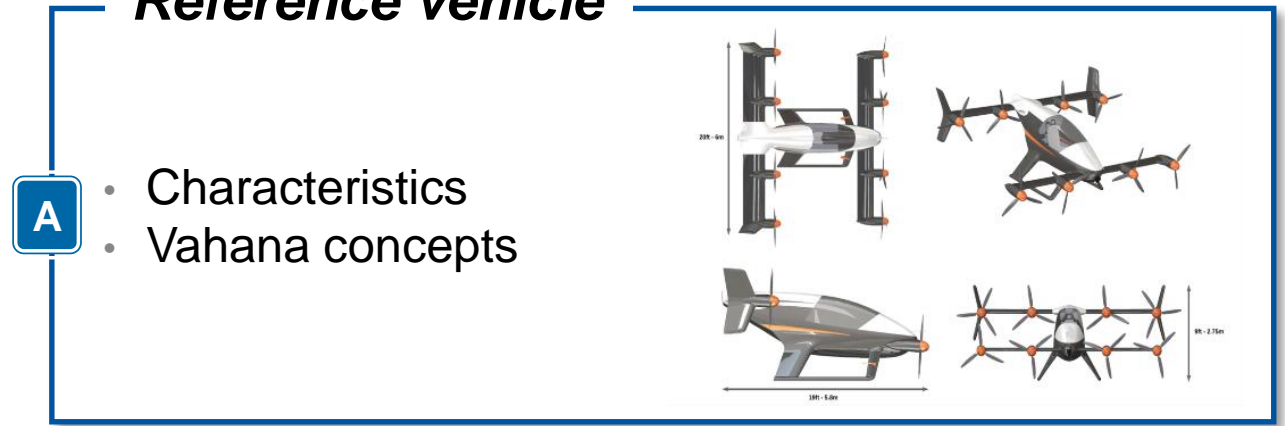

\section{Principles of fuel cells}

B - Energy storage

Equivalent specific energy

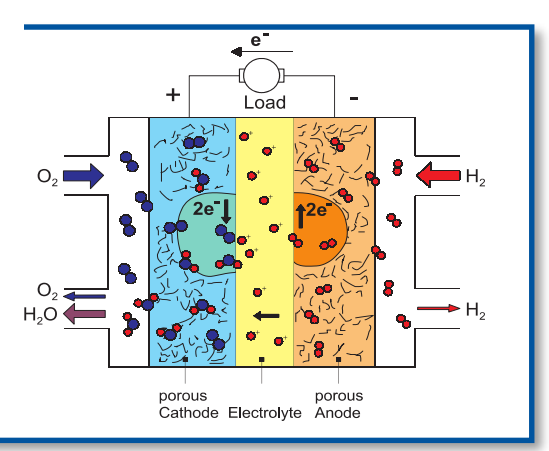

\section{Parameter Studies}

Assumptions and highlighting of affected parameters

\section{Definition of study mission}

(mission profile)

Parameter studies: range and payload

Effects on cost structure 


\section{A simple design tool provided by $A^{3}$ is used to conduct parameter studies}

Vahana is a self-piloted vertical take-off and landing (VTOL) all electric personal vehicle primary for urban mobility options

3,5

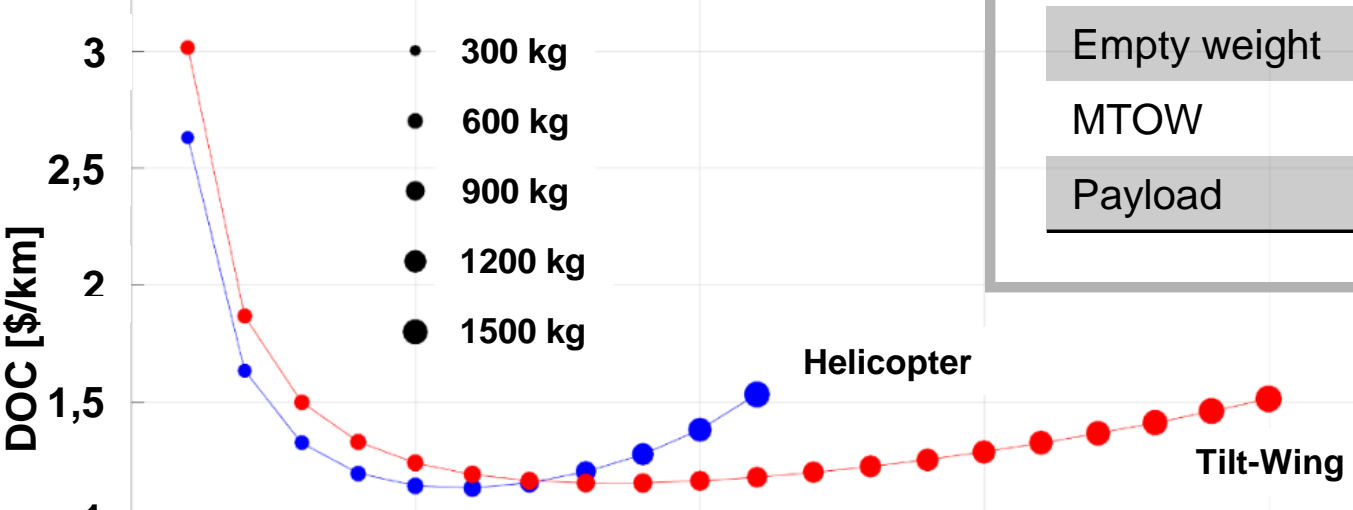

1

0,5

0

50

100

150

Range [km]

\section{Vehicle characteristics}

\begin{tabular}{lc}
\hline Characteristic & Value \\
\hline PAX capacity & 1 \\
Fuselage length & $5.70 \mathrm{~m}$ \\
Overall height & $2.81 \mathrm{~m}$ \\
Wingspan & $6.25 \mathrm{~m}$ \\
Empty weight & $475 \mathrm{~kg}$ \\
MTOW & $815 \mathrm{~kg}$ \\
Payload & $250 \mathrm{lbs}$ \\
\hline
\end{tabular}
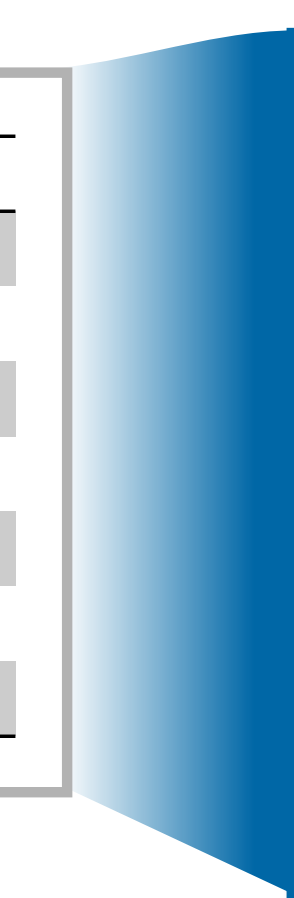

Vahana Alpha One
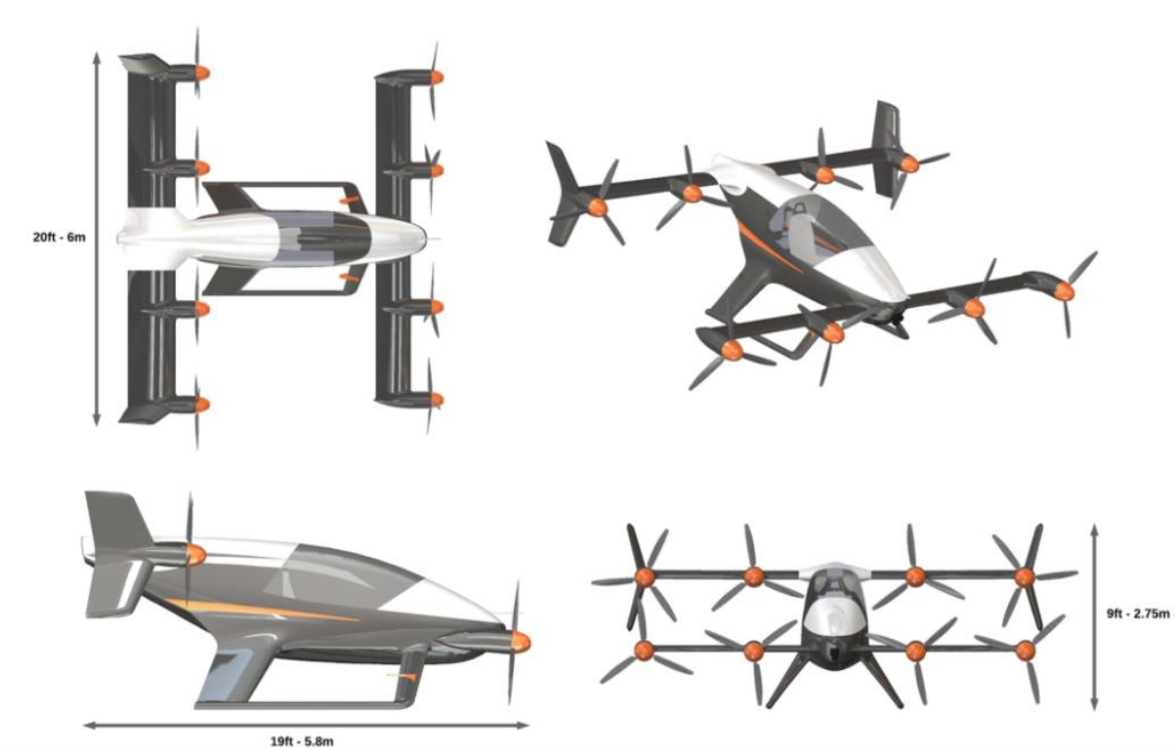

(๑) A Vahana

Size of the dots represents the respective take-off mass

First results show a cost advantage of the tilt-wing

$\Rightarrow$ configuration especially on longer distances (fixed-

wings are used to generate lift during cruise flight) 


\section{Fuel cells contain higher energy densities than batteries}

\section{Storage}

Low volumetric density calls for special storage technologies

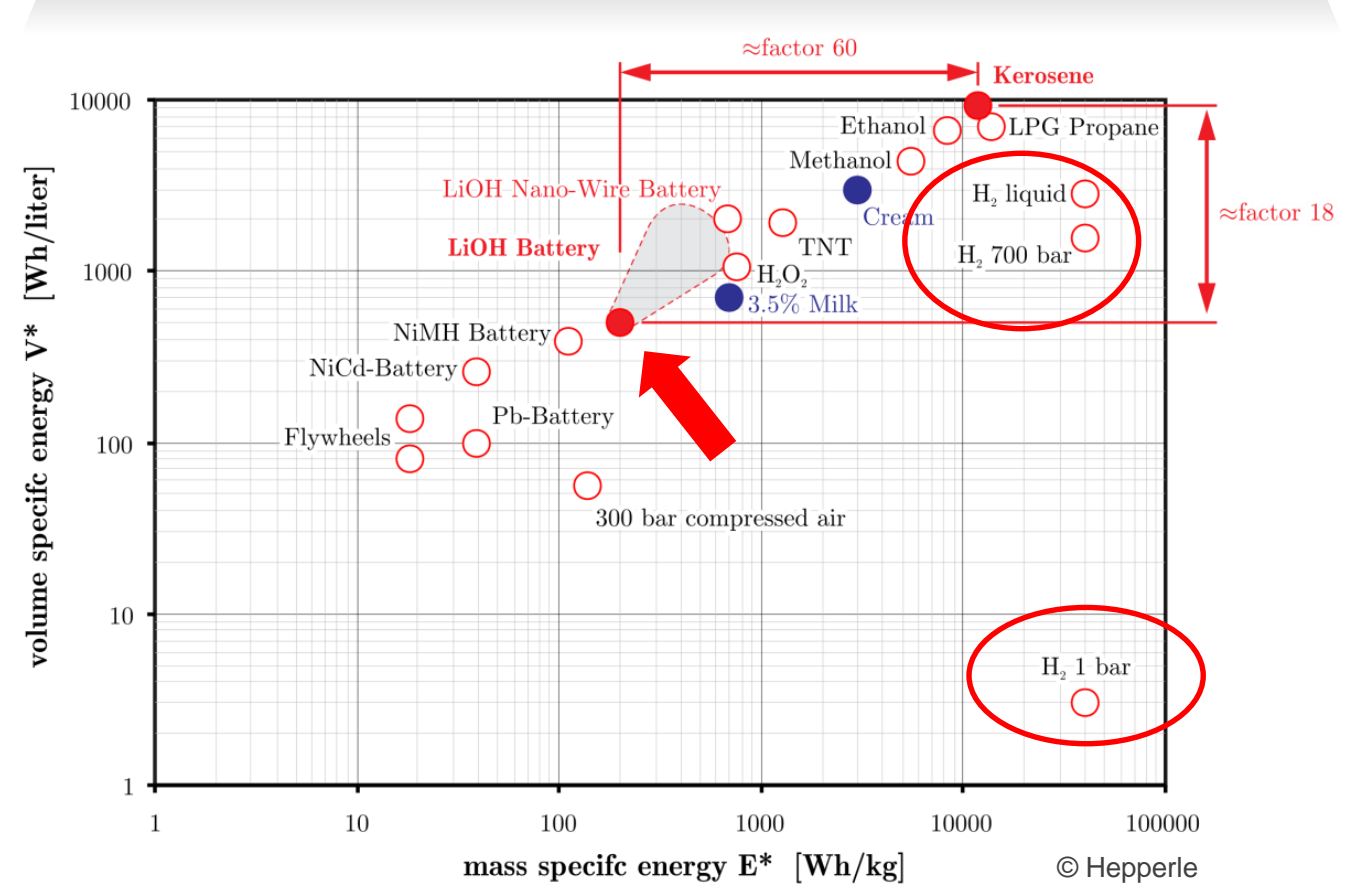

$\Rightarrow$ Hydrogen is stored under pressure, liquid or in hybrids

High pressure storage is considered most viable for small aerial vehicles (350-700 bar, volumetric energy density improved)

\section{Equivalent}

\section{A fuel cell system requires several components} such as fuel tank, hydrogen and fuel cell
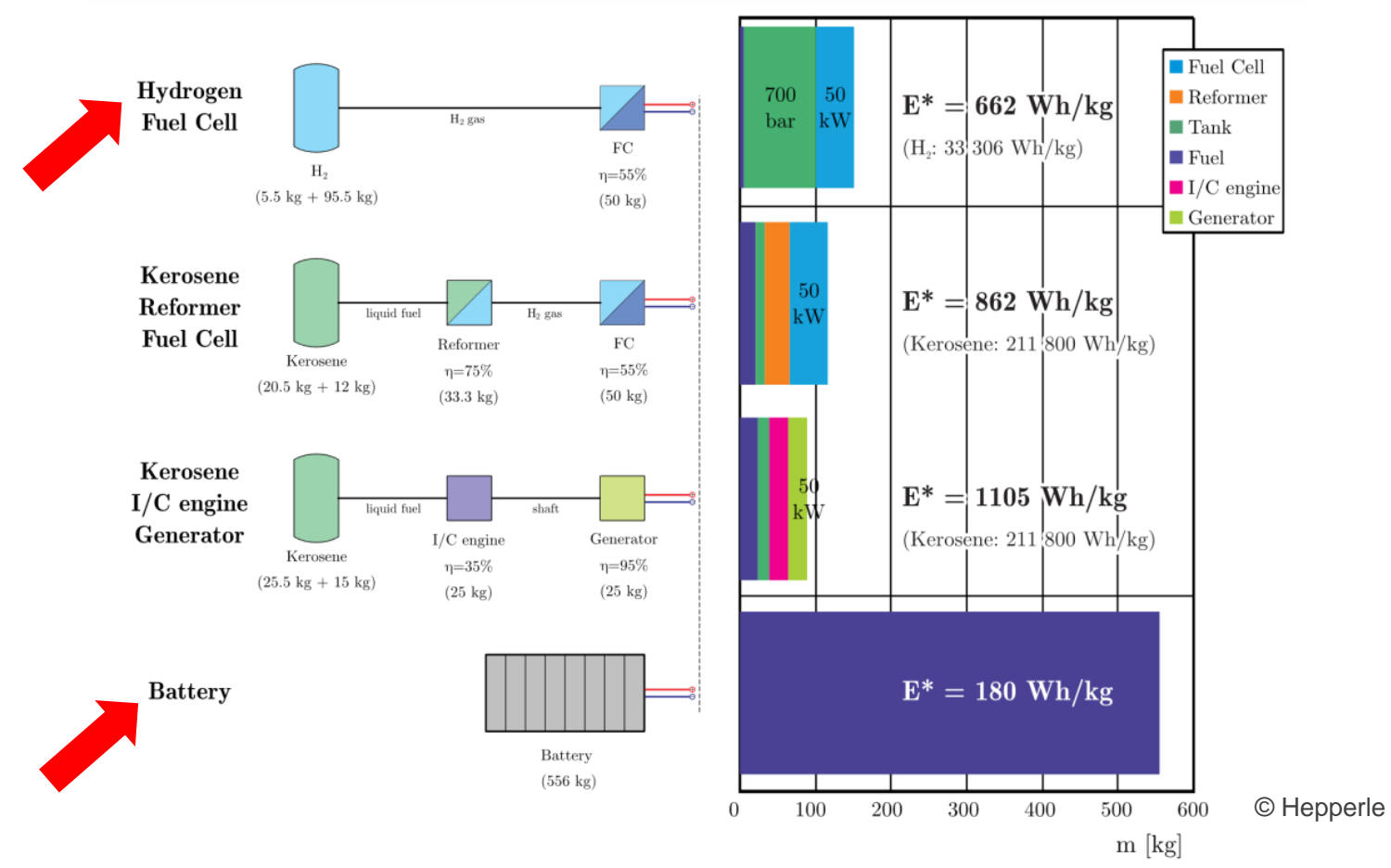

Transformation of different parameters into one equivalent specific energy is necessary for proper comparison 


\section{Considerations are based on the initial battery powered Vahana concept}

A simplified version of the original design tool is available to the public
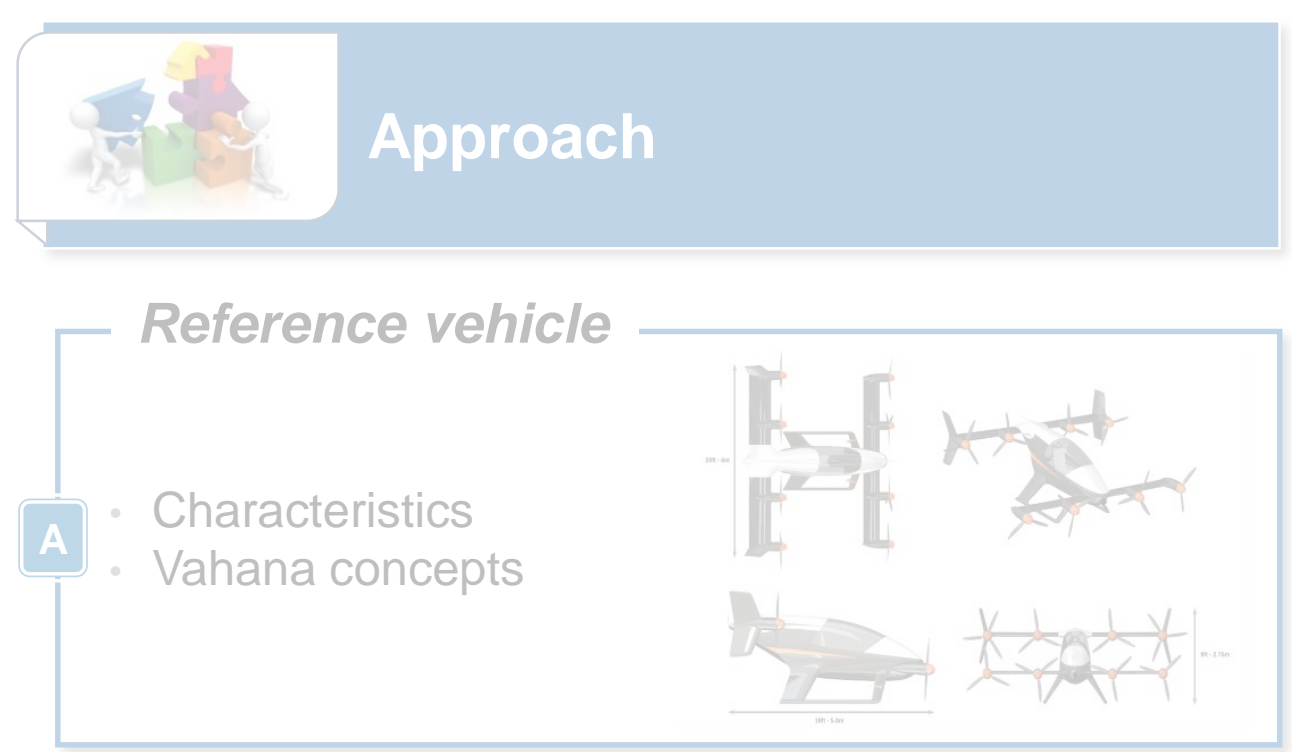

- Principles of fuel cells

B. Energy storage

Equivalent specific energy

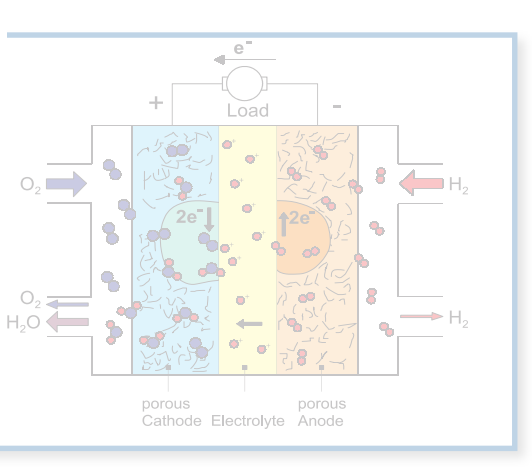

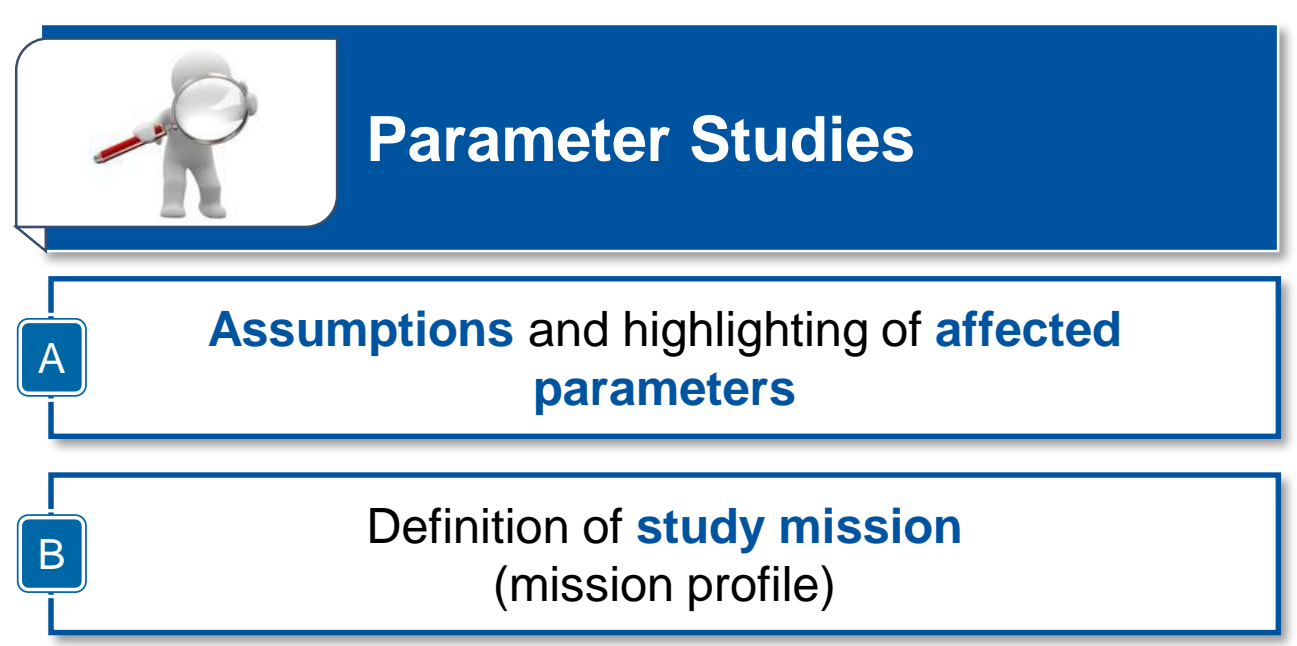
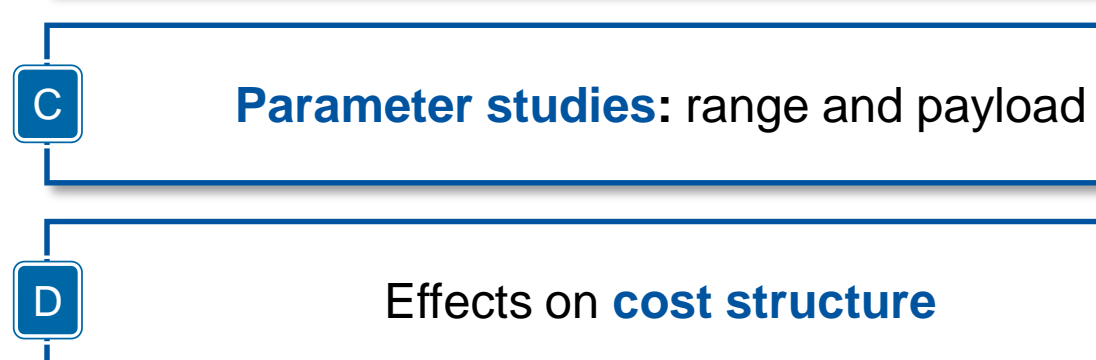

E Conclusions




\section{Initial assumptions are retained for comparability purposes}

General assumptions are based on a forecast predicting values in 2021 when Vahana is supposed to enter production

\begin{tabular}{|c|c|c|}
\hline \multicolumn{3}{|c|}{$\begin{array}{c}1 \\
\text { Performance and dimensions }\end{array}$} \\
\hline \multicolumn{3}{|c|}{$\begin{array}{l}\text { Performance and efficiencies of electric } \\
\text { powertrain unit and dimensions of the } \\
\text { vehicle }\end{array}$} \\
\hline Parameter & Value & Unit \\
\hline Battery specific energ & 230 & $\mathrm{Wh} / \mathrm{kg}$ \\
\hline Motor specific power & 5 & $\mathrm{~kW} / \mathrm{kg}$ \\
\hline Depth of discharge & 95 & $\%$ \\
\hline Fuselage width & 1 & $\mathrm{~m}$ \\
\hline Fuselage length & 5 & $\mathrm{~m}$ \\
\hline Fuselage height & 1.6 & $\mathrm{~m}$ \\
\hline Gearbox efficiency & 98 & $\%$ \\
\hline Motor efficiency & 85 & $\%$ \\
\hline
\end{tabular}

\begin{tabular}{|c|c|c|}
\hline \multicolumn{3}{|c|}{$\begin{array}{c}2 \\
\text { Manufacturing costs }\end{array}$} \\
\hline \multicolumn{3}{|c|}{ Material and production expenditures } \\
\hline Cost design & Value & Unit \\
\hline Material & 220 & $\$ / \mathrm{kg}$ \\
\hline Battery & 161 & $\$ / \mathrm{kg}$ \\
\hline Motor & 150 & $\$ / \mathrm{kg}$ \\
\hline Servo & 800 & $\$ / p c s$ \\
\hline Avionics & 30,000 & $\$$ \\
\hline Insurance & 6.5 & $\%$ aq. cost \\
\hline Facility rental & 2 & $\$ / \mathrm{ft}^{2} /$ month \\
\hline Electricity & 0.12 & $\$ / \mathrm{kWh}$ \\
\hline
\end{tabular}

\section{Which parameters are affected by a propulsion modification?}




\section{Two main design parameters must be adapted for the application of a fuel cell}

\section{Affected Parameters}

The implementation of an equivalent fuel cell is carried out by adjusting the performance values of the previous battery.

\section{Battery specific energy}

Available energy provided for propulsion (hydrogen instead of electricity)

Engine, servo components and efficiencies remain unchanged (associated

$\Rightarrow$ data can be adopted). Avionics, insurances, leasing and personnel costs are not affected by a modification

Battery costs per mass unit $(\mathrm{kg})$ and replacement cycle will change as the price of the fuel cell system will be different.

\section{Depth of discharge}

Unlike a battery, a fuel cell system can use $100 \%$ of its available energy (empty tank) 


\section{Parameter Studies: Effects on the range capacity}

\section{Range}

Payload

Payload is kept constant and all default parameters are applied

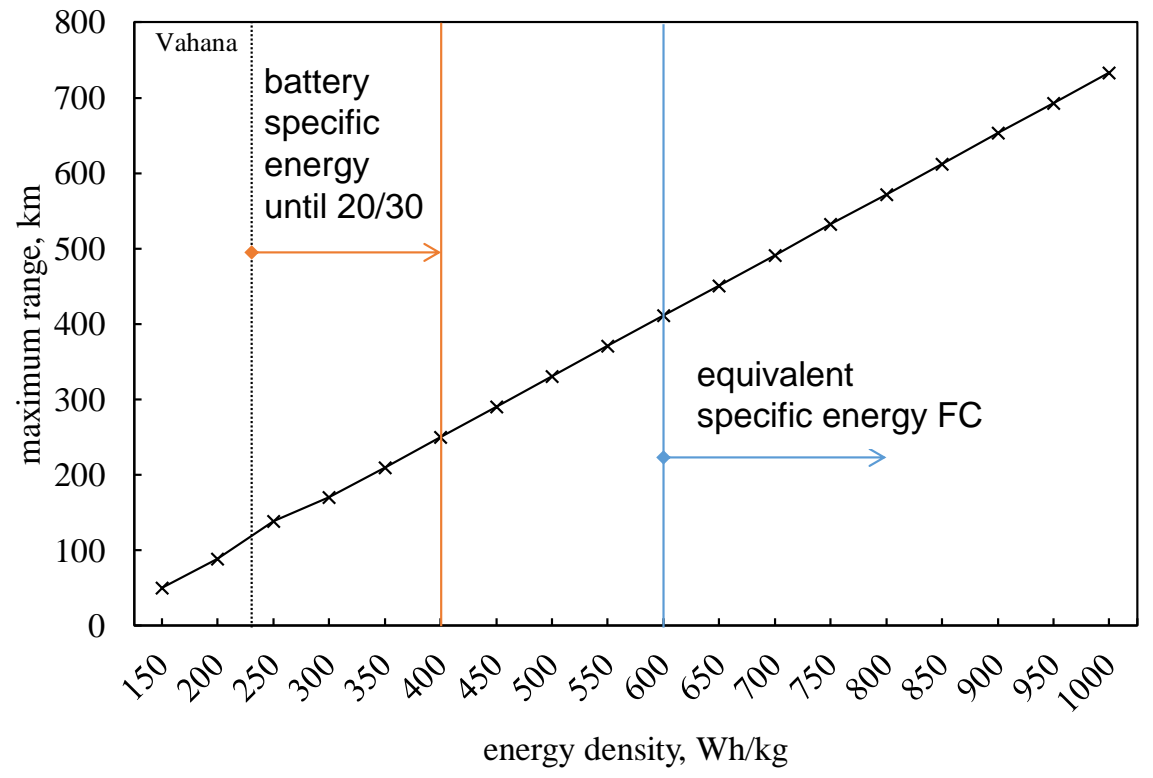

$\Rightarrow$ Range increases nearly linearly with increasing energy density

- Strong correlation between both parameters since there are no real weight effects due to empty and lighter tanks

\section{Increasing range capacity is used to} increase payload capacity

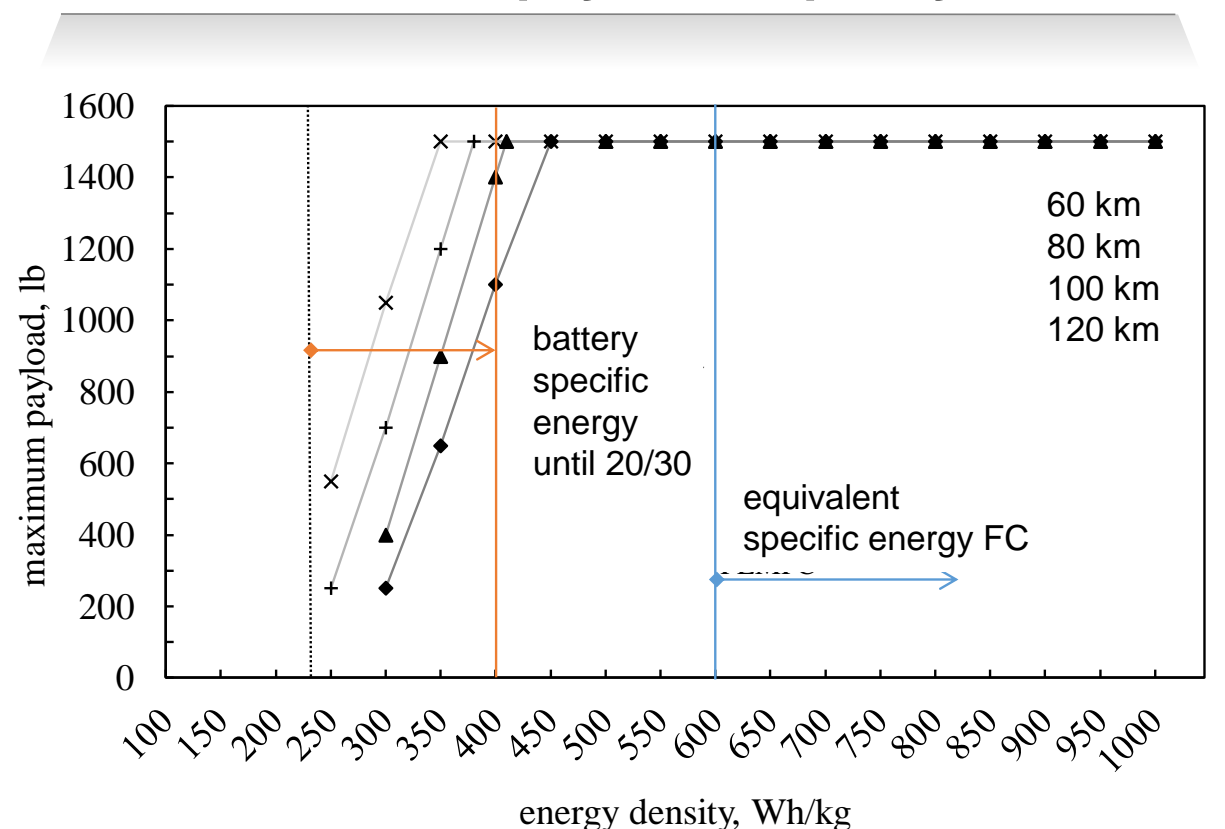

$\Rightarrow$ Buffer time increased from 20 min to 40 min due to heavier weights

$\Rightarrow$ Higher energy density results in a higher max. payload capacity

Higher energy density for a certain range apparent for certain payload if a longer range is assumed for study mission 


\section{Direct operating costs vary considerably due to different assumptions}

Lifetime of both power systems (30 min duration of flight)

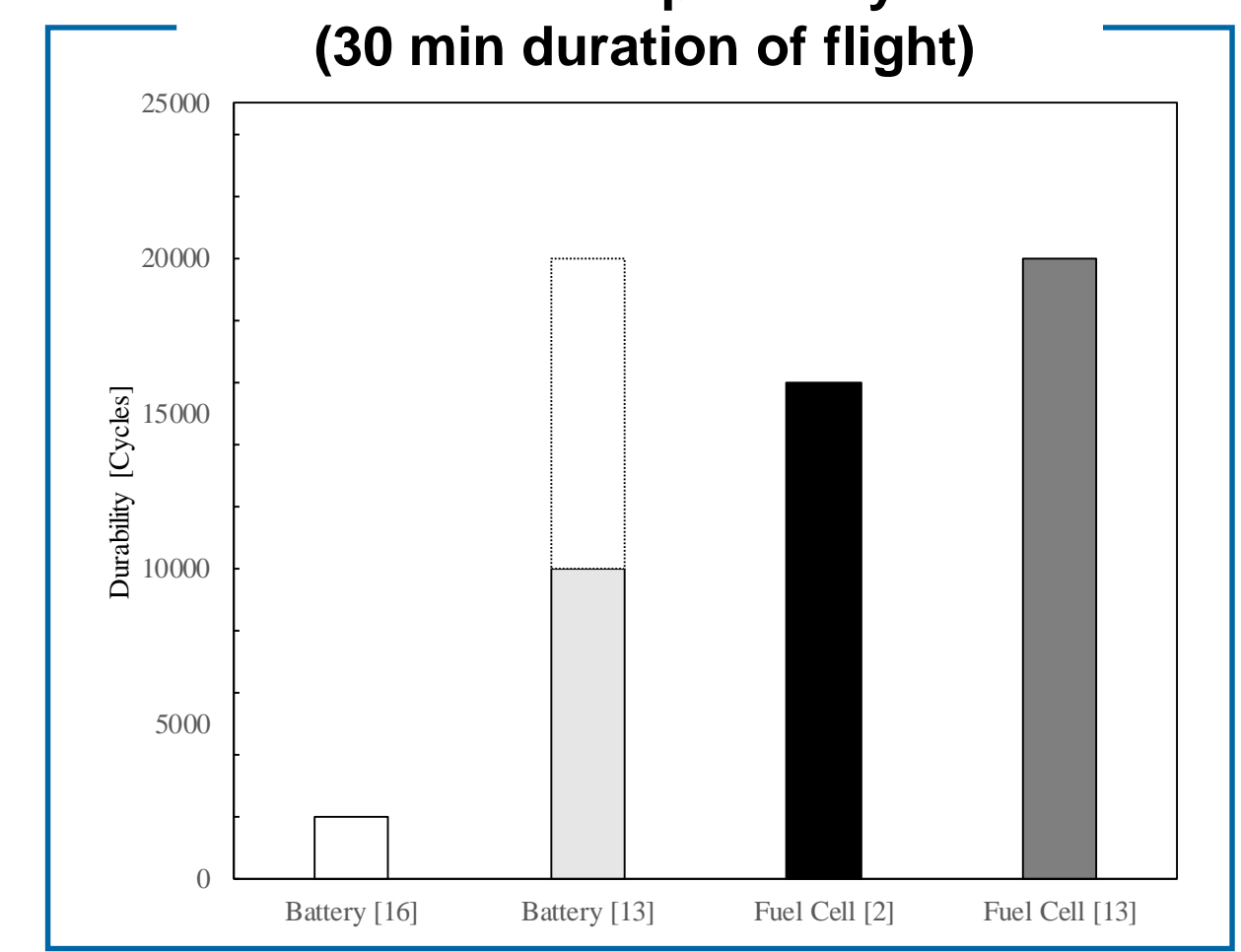

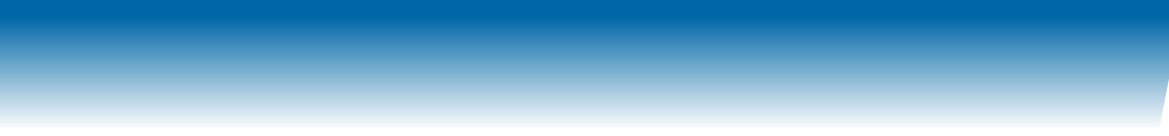

\begin{tabular}{cccc}
\hline Range & Max. power & Energy & Flight time \\
\hline $100 \mathrm{~km}$ & $\sim 200 \mathrm{~kW}$ & $112.4 \mathrm{kWh}$ & $1843.2 \mathrm{~s}$ \\
\hline
\end{tabular}

\section{Battery Costs}

battery costs $=$ energy density $*$ energy price $*$ battery weight

\begin{tabular}{lcccc}
\hline Scenario & $\begin{array}{c}\text { Energy } \\
\text { density }\end{array}$ & $\begin{array}{c}\text { Energy } \\
\text { price }\end{array}$ & $\begin{array}{c}\text { Battery } \\
\text { weight }\end{array}$ & $\begin{array}{c}\text { Total battery } \\
\text { costs }\end{array}$ \\
\hline High-price & $230 \mathrm{Wh} / \mathrm{kg}$ & $700 \$ / \mathrm{kWh}$ & $752.11 \mathrm{~kg}$ & $121,250 \$$ \\
Low-price & $400 \mathrm{Wh} / \mathrm{kg}$ & $350 \$ / \mathrm{kWh}$ & $225.77 \mathrm{~kg}$ & $31,607 \$$ \\
\hline
\end{tabular}

\section{Fuel Cell Costs}

$F C$ costs $=$ price $p$. power $*$ max power + hydrogen storage costs $*$ energy demand

\begin{tabular}{lccccc}
\hline Scenario & $\begin{array}{c}\text { Price per } \\
\text { power }\end{array}$ & Max power & $\begin{array}{c}\text { Hydrogen } \\
\text { storage costs }\end{array}$ & $\begin{array}{c}\text { Energy } \\
\text { demand }\end{array}$ & $\begin{array}{c}\text { Total FC } \\
\text { costs }\end{array}$ \\
\hline High-price & $230 \$ / \mathrm{kW}$ & $200 \mathrm{~kW}$ & $33 \$ / \mathrm{kWh}$ & $112.4 \mathrm{kWh}$ & $49,709 \$$ \\
Low-price & $40 \$ / \mathrm{kW}$ & $200 \mathrm{~kW}$ & $10 \$ / \mathrm{kWh}$ & $112.4 \mathrm{kWh}$ & $9,124 \$$ \\
\hline
\end{tabular}

Total costs fluctuate significantly due to deviating technological maturity and uncertainty about future price developments of energy sources. More detailed investigations necessary, which emphasize the costs 


\section{Key takeaways and future work}

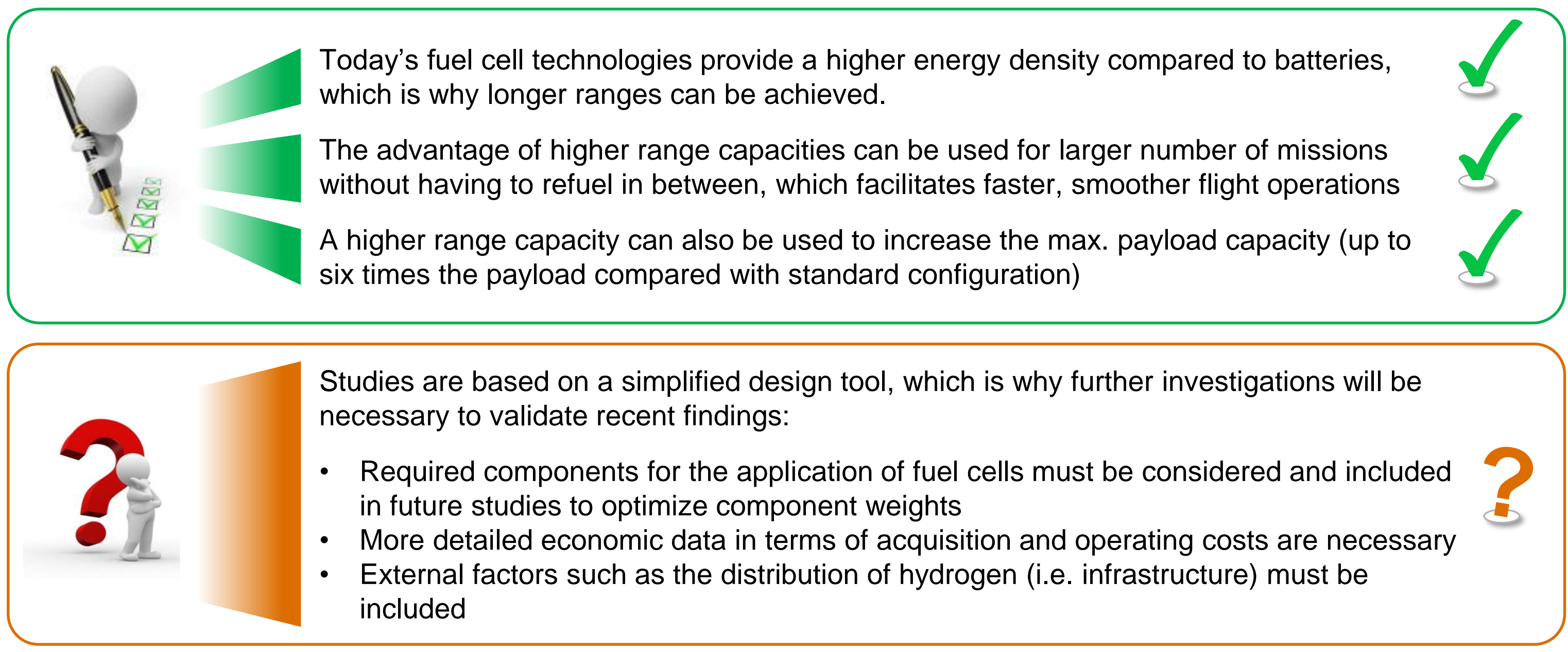




\title{
Thank you.
}

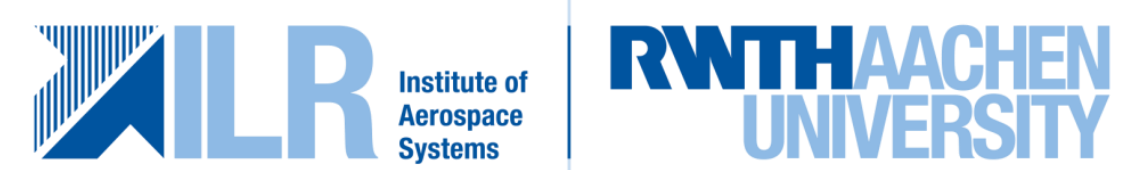 \\ Wuellnerstrasse 7 \\ 52062 Aachen | GERMANY \\ Tel +49 $24180-96899$ \\ Fax +49 $24180-92233$ \\ Research Assistant \\ husemann@ilr.rwth-aachen.de \\ www.ll.rwth-aachen.de
}

